\begin{tabular}{|ccc}
\hline Sournals & $\begin{array}{c}\text { INTERNATIONAL JOURNAL OF } \\
\text { ORGANIZATIONAL LEADERSHIP }\end{array}$ & $\begin{array}{c}\text { INDUSTRIAL } \\
\text { MANAGEMENT } \\
\text { INSTITUTE }\end{array}$ \\
\hline
\end{tabular}

\title{
Transformational and transactional leadership: Which one is more effective in the education of employees' creativity? Considering the moderating role of learning orientation and leader gender
}

\author{
Pejman Ebrahimi $^{1^{*}}$, Mousa Rezvani Chamanzamin ${ }^{2}$, Najmeh Roohbakhsh ${ }^{3}$, Jafar \\ Shaygan $^{4}$
}

\author{
${ }^{1}$ Department of Management, Rasht Branch, Islamic Azad University, Rasht, Iran \\ ${ }^{2}$ Department of Management, Astara Branch, Islamic Azad University, Astara, Iran \\ ${ }^{3}$ Young Researchers and Elite Club, Sirjan Branch Islamic Azad University, Sirjan, Iran \\ ${ }^{4}$ Department of Management, Rasht Branch, Islamic Azad University, Rasht, Iran
}

\begin{tabular}{l}
\hline \\
Keywords: \\
Transformational \\
Leadership, Transactional \\
Leadership, Employee \\
Creativity, Learning \\
Orientation, Leader \\
Gender \\
\hline Received \\
10 September 2016 \\
Received in revised form \\
20 December 2016 \\
Accepted \\
21 December 2016 \\
\end{tabular}

\section{Abstract}

Correspondence:

Pejman.ebrahimi77@gmail.com

\begin{abstract}
This study aimed at investigating the effect of transformational and transactional leadership on education of employees' creativity by considering the moderating role of learning orientation and leader's gender. The study hypotheses were based on the impact of transformational and transactional leadership styles on employees' creativity. In this regard, the study questionnaire is distributed among 548 people of department of education employees. Using structural equation modeling the relationships between variables were investigated. The findings showed that the female leaders were more effective than male leaders on transforming schools. Moreover, the results showed that the learning orientation moderates the connection of both leadership styles and employees' creativity.
\end{abstract}




\section{Introduction}

Understanding the point that how the schools succeed and continue their success has a great importance (Wang, Gurr, \& Drysdale, 2016). The goal of transformational schools is to guide the members of school accurately. If a school wants transformation, it should apply various methods in various courses. Also, it encourages all members to try hard continuously, because various members of school have different educational expectations regarding school transformations. Thus, the managers of schools need leadership development in respect of school improvement plans or processes (Yang, 2014). Every organization focusing on leadership effects can act more successfully than other organizations. This point is due to the fact that the leaders in the organizations play a key role in respect of measuring external environment, providing instructions, guiding the employees to face with challenges, and creating a kind of organizational superiority to continue progress and transformation (Chu \& Lai, 2011; Odumeru \& Ifeanyi, 2013). Moreover, the leadership styles has been reported as a strategic factor impacting on the innovation and sharing knowledge which enables the leaders of organizations to merge, share, and use knowledge innovatively (Mushtaq \& Bokhari, 2011). Thus, the researchers have studied the leadership concept during the years and concentrated on two types of leadership widely including transformational and transactional leadership (Masa'deh, Obeidat, \& Tarhini, 2016).

Transformational leadership is one of the central and the most effective leadership models in the field of education and training management (Berkovich, 2016; Bush, 2014; Hallinger, 2003). Transformational leadership refers to the charismatic role and inspiring measures of leader that affect on the employees to perform their duties beyond specified expectations in the formal job descriptions (Dvir, Eden, Avolio, \& Shamir, 2002). The favorability of transformational leadership theory in the educational leadership cannot be understood separated from the current change-oriented educational policy environment that focuses on the educational restructuring transformation in the twenty-first century (Hallinger, 1992; Leithwood, 1994). It has been stated in many studies that transformational leadership has five important dimensions including idealized attributes, idealized behaviors, inspirational motivation, intellectual stimulation, and individualized consideration (Bass, 1998; Bass \& Avolio, 1994; Mittal \& Dhar, 2015). The contemporary studies of successful leadership schools have investigated the relationship between leadership models and educational results. The focus of previous studies shows that transformational leadership has a positive impact on specific educational results including leaders' effectiveness, teachers' overall job satisfaction, and students' studying progress(Eyal \& Roth, 2011; Leithwood \& Sun, 2012; Menon, 2014).In transactional leadership, among other leadership styles, some leaders monitor both individual and team performance in order to predict errors and do required corrective measures by transactional behaviors (Howell \& Avolio, 1993). Transactional leadership refers to the transactional relationship between leaders and subordinates in a way that the followers possess rewards or positions for accomplishing the leaders' wishes. Transactional leadership consists of two forms, namely contingent rewards and management by exceptions (Rafferty \& Griffin, 2004; Yulk, 2010). Transactional leadership has been composed of three components including contingent reward, active management by exception, and passive management by exception (Bass \& Avolio, 2004). 
Many researchers have investigated the relationship of transformational leadership and employees' creativity in the organizations (Shin \& Zhou, 2003; Wang \& Rode, 2010; Zhou \& Shalley, 2008). In many previous studies, the role of transformational leadership in promoting and growing the creativity of employees has been stated and this leadership style has obtained very high favorability among organizational researchers and inspiring followers with regard to its unique method (Wang\& Cheng, 2010). Moreover, transactional leadership is more appropriate for organizational relationships which have features such as closer organizational culture, inflexible operational systems and processes, defensive strategies, and satisfactory performances (Vera \&Crossan, 2004). Innovation through creativity is considered as one of the most important factors of success and competitive advantage in the organizations. Many research show that both types of transactional and transformational leadership as well as organizational climate have important results on people's creativity ( $\mathrm{Si} \&$ Wei, 2012).Employee creativity is essential for the growth of every organization and greatly depends on the dynamicity of the working teams within the organizations (Bai, Lin, \& Li, 2016). Employees' creativity is essential for the survival and competition of organization (Shalley, Zhou, \& Oldham, 2004). This statement refers to the production of new and useful ideas about the methods, services, or procedures in the workplace (Amabile, 1996). Employees' creativity is an inevitable part of innovation that not only includes producing new ideas, but also includes performing new ideas (Zhou, 2003). Creativity is considered as an important factor which has been conceptualized as a necessary prerequisite for innovation (Joo, McLean, \& Yang, 2013). Thus, many scholars and researchers have focused on the way of increasing employees' creativity. The majority of scientists, who have investigated the employees' creativity records, have found out that the leader's positive behavior is a vital precursor of employees' creativity (Tierney, 2008).

This research investigates the role of the moderating variables of learning orientation and leaders' gender in relationship with leadership styles and employees' creativity. Learning orientation has been conceptualized as a set of values that affects on the ratio that an organization is satisfied of its applied theories (Argyris \& Schon, 1978). Learning orientation is described as a process of information acquisition, information dissemination, and shared interpretation that increases two types of individual and organizational satisfaction with regard to direct effects of results (Kaya \& Patton, 2011). Learning orientation has been composed of four dimensions in many studies including commitment to learning, shared vision, openmindedness, and intra-organizational knowledge sharing (Calantone, Cavusgil, \& Zhao, 2002; Hurley \& Hult, 1998; Jyoti \& Dev, 2015; Moorman \& Miner, 1998).Learning orientation is defined as a set of beliefs, attitudes, and measures for teachers (Opfer, Pedder, \& Lavicza, 2011). Generally, the gender of leaders in the educational organizations is important. Considering the leadership styles, it is important to identify the kind of managers as well as the types of management leadership styles which have more effects on the employees' creativity. According to the declaration of information and communication technology center of ministry of education and training, the number of employees and teachers of education and training organization is one million and 13 thousand and 655 people in Iran in 2016. The male and female teachers and employees compose 481 and 532 thousand people, respectively. Among them, 358 thousand teachers were working at elementary level, about 232 thousand of them at 
guidance level, and about 307 thousand of them at high school level, and finally other 61 thousand of them in the administrative section and higher education of Farhangian University. Moreover, the number of exceptional teachers is also 21 thousand and 500 people. The genderbased approach suggests that women take and develop a feminine leadership style and men take and develop a masculine leadership style (Eagly, Makhijani, \&Klonsky, 1992). Although leadership literature has recently emphasized on more feminine behavior, effective leadership has been perceived as the leadership that requires stereotypical masculine traits (Brandt \& Laiho, 2013; Brenner, Tomkiewicz, \& Schein, 1989). The masculine characteristics are usually applied in the initial stages of construction phase, while the feminine characteristics are applied in theoretical consideration phase (Spence \& Helmreich, 1978; Williams \& Best, 1982).Construction phase includes setting and determining the work behaviors and goals and then maintaining a strong work orientation, while consideration phase includes showing concern for subordinates' feelings, participation, satisfaction, and friendship(Brandt \& Laiho, 2013). The previous studies have shown that the men compared with women are to some extent more physically arrogant and aggressive in their behavior, while the women express more their feelings and emotions (Chesler, 2001; Simmons, 2002).Perhaps the most important research gap in the literature is related to the lack of experimental evidences in a wide range, in a way that the moderating roles of leaders' learning orientations and genders cause differences in the relationship between leadership styles and employees' creativity. It is considered as an incentive point to implement this experimental research. Therefore, this research has been performed to distinguish and fill the existing gap in the research literature and also attract the attention of schools managers about research findings. The research hypotheses of this study tried to determine which one- transformational and transactional leadership styles-is more effective on the educational employees' creativity and training by considering the moderating role of learning orientation and leader gender.

\section{Research Theoretical Framework and Hypotheses}

Figure 1 shows the conceptual model of this research. This model shows the relationship between transformational and transactional leadership styles and employees' creativity. Moreover, the moderating role of leaders' learning orientations and genders are also investigated.

One of leadership approaches that has attracted considerable attention of many scholars to itself is transformational leadership (Northouse, 2007). This type of leadership is considered as the most effective leadership theory during the last two decades (Judge \& Piccolo, 2004). The difference between transformational and transactional leadership was firstly proposed by Burns in 1978. He developed his theory based on his research findings about political leaders. Burns (1978) describes transformational leadership as a process not as a set of specific behaviors. According to his ideas, those leaders are considered as transformational ones who intend to have higher ideals, high ethical standards, and empowering features to make deep and basic changes. Burns also argued that the transformational leadership is something more than an ordinary relationship between the leader and followers in the transactional leadership (Yahaya \& Ebrahim, 2016). Transformational leadership provides deeper levels of relationship and high 
levels of commitment, performance, and ethical principles between the leaders and followers (Burns, 1978).

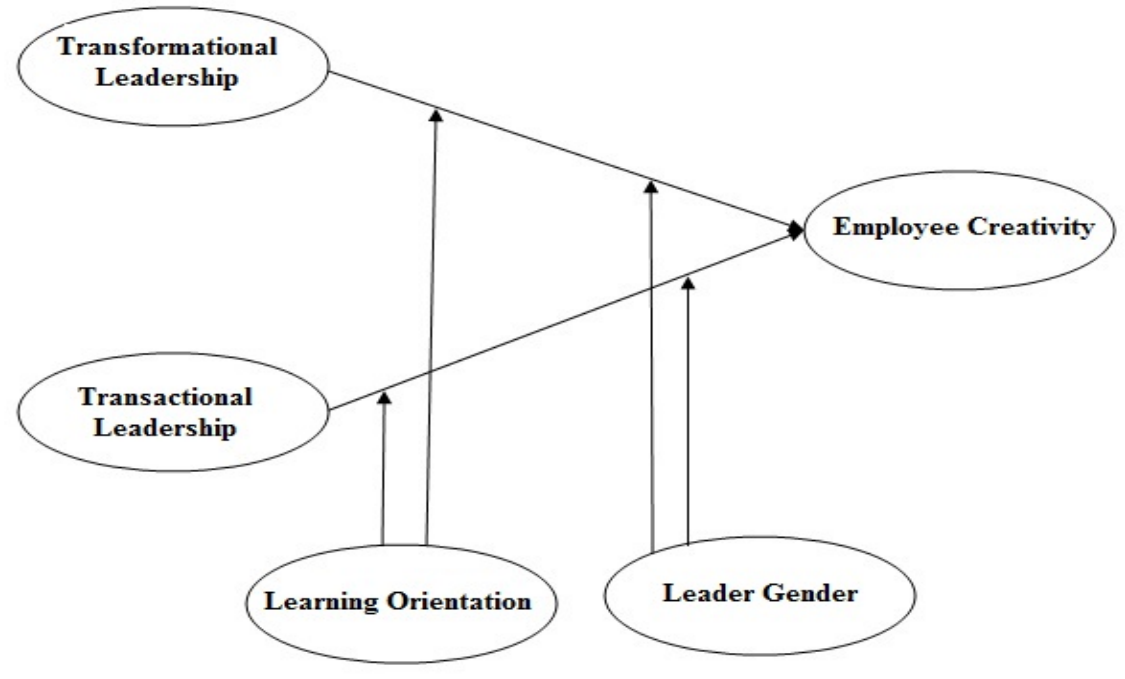

Figure 1. The conceptual model

Research in the field of transformational leadership reveals the significance of this type of leadership in the individual and organizational levels (Wang \& Howell, 2010). Transformational leadership focuses on the leaders' transformational abilities to create transformation in their employees through increasing motivation, making them committed, and empowering them in respect of accessing the organizational goals (Yulk, 2010).Although the transformational leadership theory encounters with some criticisms in the educational management field, some critics state that various dimensions of transformational leadership remain unspecified (Van Knippenberg \& Sitkin, 2013). Hsiao and Chang (2011) performed a research in 63 high schools of Taiwan to select a sample of 330 teachers and then a multifactor leadership questionnaire (MLQ)was distributed among them. The correlation higher than 0.75 was reported among five dimensions of transformational leadership. Bogler (2001) and Nir and Hameiri (2014) performed exploratory factor analyses in their studies and investigated that the dimensions of transformational leadership were not able to repeat and keep the required continuity within their multidimensional structures (Bogler, 2001; Nir \& Hameiri, 2014). Another criticism related to the transformational leadership theory comes back to the lack of having enough experimental evidences that other leadership styles have. Another metaanalysis study showed that transformational leadership was strongly correlated with the contingent reward which was considered as one of transactional leadership dimensions (Judge $\&$ Piccolo, 2004). Transactional leaders are those who provoke employees' motivation through creating satisfaction based on requirements such as payment or reward in order to return employees' effort (Sadler, 2003; Yulk, 2010). Transactional leadership can provide satisfactory result in the short time, while transformational leadership can result in creativity and productivity during a long term effort (Bass, 1985). Leadership is considered as a factor that can affect on employees' training and creativity. The leaders increase the likelihood of taking creative outputs by creating appropriate organizational structure, organizational climate and 
culture, and measures of organizational resources. Leadership behavior can be effective on employees' perception of workplace that can affect on employees' creativity by itself (Amabile, Schatzel, Moneta, \& Kramer, 2004). The most important leadership behaviors that affects on the employees' creativity are encouraging employees to express their viewpoints, offering on time and constructive feedback, providing independence conditions, offering a high level of social support, expressing concern for the employees' feelings, creating balance between the employees' freedom and responsibilities, and creating necessary conditions to develop employees' skills (Amabile, 1997; Amabile et al., 2004; Andrews \& Ferris, 1967; Carson \& Carson, 1993; Deci \& Ryan, 1987; Jaskyte \& Kisieliene, 2006; Oldham \& Cummings, 1996; West, 1989). The leaders in the education and training field should search for new and creative ways that can respond the demands and requirements in our rapidly changing world. The new concept of leadership is not summarized in the performance of managers, but includes a wide range of people working in the education and training domains. It seems that change is always associated with resistance. This is a serious challenge for all people who play a role in education and training. Creativity and innovation is among the most important goals and missions of education and training and educational organizations. In the development and strengthening the creativity in the educational organizations, creative and innovative management plays an effective and impressive role more than all other factors, because the educational managers' attitudes and beliefs towards creativity and innovation in organizations can change the educational environment to the center of changes and innovation. If the schools' managers in addition to the managerial skills have the knowledge and the skill of creativity and innovation, the backgrounds for creating and growing creativity in the employees are provided (Shalley \& Gilson, 2004). With regard to the presenting literature review, the following hypotheses are proposed:

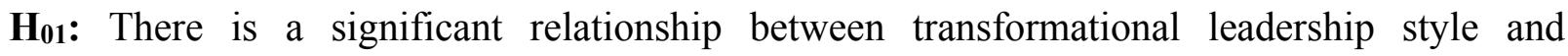
employees' creativity.

$\mathbf{H}_{\mathbf{0 2}}$ : There is a significant relationship between transactional leadership style and employees' creativity.

\section{Moderating Role of Learning Orientation}

Organizational learning is a process through which the organization interprets, changes, and stores new knowledge and then applies this knowledge for improving the organizational activities (Grant, 1996; Huber, 1991). The majority of organizational management scientists and strategists agree that organizational learning includes acquiring and applying new knowledge and skills (Cohen \& Levinthal, 1990; Muthusamy \& White, 2005). However, the organizations cannot create all of their required knowledge and technology, because they have limited resources (Dyer \& Singh, 1998; Muthusamy \& White, 2005; Zander \&Kogut, 1995).

Learning orientation is the reflector of a set of values related to the knowledge showing that it has a direct impact on the higher learning (Nasution, Mavondo, Matanda, \& Ndubisi, 2011). Our general understanding of teachers' professional learning still has ambiguities (Billett, Fenwick, \& Somerville, 2006). Learning orientation is regarded as an important component of teachers' professional work transformation (Hodkinson \& Hodkinson, 2005). Leaning at workplace has been officially recognized as a vital factor for teachers' success in the 
classroom. Learning at workplace has remarkable features which distinguish it from traditional learning like attending formal courses or conferences outside their workplaces (Retallick, 1999).A review on leadership and organizational learning literature shows that leadership has a key contribution in sharing organizational learning (Khalifa \& Ayoubi, 2015). The role of leadership has been considered in creating an open atmosphere and mental safety as a very important factor for organizational learning (Argyris \& Schon, 1996; Edmondson, 1999; Schein, 1993). Numerous studies have investigated the relationship of transformational leadership, transactional leadership, and organizational learning. Many of these studies have confirmed the vital role of transformational leadership in supporting organizational learning (Coad \& Berry, 1998; Chang \& Lee, 2007; Jansen, Vera, \& Crossan, 2009; Kurland, Peretz, \& Hertz-Lazarowitz, 2010; Nafei, Khanfar, \&Kaifi, 2012; Theodore, 2013). Patnaik, Beriha, Mahapatra, and Singh (2013) confirmed the role of transformational leadership in the higher education institutes for creating long-term commitment in line with the organizational learning. Some studies about transactional leadership have shown positive relationship between this leadership style and organizational learning (Coad \& Berry, 1998; Jansen et al., 2009; Nafei et al., 2012; Vera \& Crossan, 2004). Jansen et al. (2009) stated that the transactional leadership behaviors cause the improvement and expansion of existing knowledge structures. Some studies have also shown negative relationship between transformational leadership and organizational learning (Amitay, Popper, \& Lipshitz, 2005). Considering the concept of organizational learning, management literature provides an appropriate background for innovation and creativity (Carneiro, 2000). However, no adequate evidences have been offered in literature in connection with learning and innovation processes yet (Darroch \& McNaughton, 2002). The literature of organizational learning requires a kind of experimental validation whereby the relationship between organizational learning principles and creativity and innovation can be determined. With regard to the presented literature, the following hypotheses are proposed:

$\mathbf{H}_{03}$ : There is a significant relationship between transformational leadership, and employee creativity, with regard to the moderating role of learning orientation.

H04: There is a significant relationship between transactional leadership, and employee creativity, with regard to the moderating role of learning orientation.

\section{Moderating Role of Leader Gender}

The various stereotypes and expectations of male and female leaders might be considered different due to the different personality types (Brandt \& Laiho, 2013). According to Eagly, Karau, and Makhijani (1995) and Northouse (2007) stated that males and females leaders became more effective when their leadership styles are congruent with regard to their gender norms. Generally, males are known with the traits like being assertive, independent, logical, and decisive, while the females are expected to show their concern for others, intimacy, and usefulness (Hoyt, Simon, \& Reid, 2009).Some studies have shown that female leaders are more transformational than male leaders (Bass, 1999; Carless, 1998; Northouse, 2007) while some other ones have shown that there is no difference in the leadership styles with regard to the gender(Brown \& Reilly, 2008; Kent, Blair, Rudd, \& Schuele, 2010; Manning, 2002; Oyster, 
1992).Brandt and Laiho (2013) referred to the existing differences of leadership behaviors with regard to the gender norms in which the females showed more empowering behaviors while the males showed more competitive ones. According to the leaders and subordinates, the factors such as gender and personality can affect on the leadership behaviors; for instance, the extroverted and intuitive male leaders along with those who depict perceptual dimensions know themselves more than their male counterparts who are introverted, emotional, and judgmental. This viewpoint has been confirmed by subordinates about perceptual male leaders. Using a research and development (R\&D) sample, Wang, Chiang, Tsai, Lin, and Cheng (2013) proved that how authoritative and open-minded leaders could interact with the role of gender and consequently dependent performances such as performing duty, citizenship behavior, and creativity. This research developed the role of congruity theory by choosing the general authority rules and through which offered a more comprehensive framework about the impact of leaders' gender on the leadership styles and dependent performances. The results of study showed that the negative relationship between authoritarian leadership and subordinates' performance are stronger for the females than male leaders. Furthermore, the positive relationship between liberalism leadership and subordinates' performance are stronger for the male than female leaders. In addition to the involvement of leaders with the behaviors proportionate to the gender, the useful strategy is to take into account the behaviors that are considered as positive deviations from their gender norms. With regard to the importance of leaders' gender norms in taking leadership styles, the following hypotheses are proposed:

$\mathbf{H}_{05}$ : Male transformational leaders in comparison to the female transformational leaders have more impact on the employees' creativity of education and training.

Ho6: Male transactional leaders in comparison to the female transactional leaders have more impact on the employees' creativity of education and training.

\section{Method}

\section{Participants}

The statistical population of this study consisted of 1136550 employees and teachers of education and training organization. About 481 ones of them belong to the male teachers and employees while 532 of them are female teachers and employees. To determine the exact sample size, Cochran Formula was used $(n=514)$. At pretest stage, in total, 600 questionnaires were distributed and 548 of them were returned. Thus, totally 548 people of the employees and teachers of education and training organization participated at the various levels such as elementary, guidance, and high school. Generally, 56.75 percent (311 people) of participants were female. The average age of sample was 27.38 years old. On average, the participants had at least 5.96 years of working experience.

\section{Procedure}

The goal of study was explained to the participants before filling out the questionnaires and this assurance was given to them that all responses will remain anonymous and confidential. After justifying the participants and providing their conscious satisfaction, the questionnaires were 
distributed among the participants to fill out. The participants were also requested to specify their gender, age, and working experience.

\section{Measures}

Multiple-choice items in a 5-point Likert scale ranging from 1 (strongly disagree) to 5 (strongly agree) were used. These items were based on transformational, transactional leadership, employees' creativity, and organizational learning (Bass \& Avolio, 1995; Hult \& Ferrell, 1997; Jyoti \& Dev, 2015).

Table 1

Dimensions of the Questionnaire \& the Number of Items

\begin{tabular}{llc}
\hline Dimensions & & Number of Items \\
\hline Transformational Leadership & Inspired Motivation & 4 \\
& Intellectual Stimulation & 4 \\
& Individual Consideration & 4 \\
& Idealized Influence Behavior & 8 \\
Transactional Leadership & Leader's Contingent Reward Behavior & 4 \\
& Active Management & 3 \\
Employees' Creativity & & 3 \\
Organizational Learning & & 10 \\
\hline
\end{tabular}

\section{Exploratory Factor Analysis}

To determine the reliability of questionnaire, Exploratory Factor Analysis and then Confirmatory Factor Analysis were used. In the Exploratory Factor Analysis, the KMO indicator and Bartlett's Test of Sphericity have been estimated. Based on these two tests, the data was considered to be more appropriate for running Confirmatory Factor Analysis when the KMO value was more than 0.6 and close to one. Furthermore, the significant value of Bartlett's Test was less than 0.05 . Table 2 presents the summary of EFA results to examine the validity of questionnaire.

Table 2

Summary of EFA Results to Examine the Validity of Questionnaire

\begin{tabular}{clcccc}
\hline & & $\begin{array}{c}\text { Transactional } \\
\text { Leadership }\end{array}$ & $\begin{array}{c}\text { Transactional } \\
\text { Leadership }\end{array}$ & $\begin{array}{c}\text { Employee } \\
\text { Creativity }\end{array}$ & $\begin{array}{c}\text { Learning } \\
\text { Orientation }\end{array}$ \\
\hline KMO Value & & 0.85 & 0.90 & 0.92 & 0.87 \\
Bartlett's & $\mathrm{X}^{2}$ Value & 3633.40 & 2003.12 & 3755.09 & 2528.60 \\
Test & Degree of Freedom & 190 & 21 & 78 & 45 \\
& $(\mathrm{Sig})$ & 0.00 & 0.00 & 0.00 & 0.00 \\
\hline
\end{tabular}

Regarding the results of KMO and Bartlett's tests (Table 2), the confirmatory factor analysis could be implemented on the questions of questionnaire.

\section{Results}


In data analysis, the inferential statistics such as Structural Equation Modeling (SEM) which includes Confirmatory Factor Analysis and Path Analysis were used. The software which were used for data analysis were Amos and SPSS. To validate the content value of each indicator in measuring the proposed concepts and structures, the validity of designed model was analyzed through applying structural equation modeling method. According to Table 3, the majority of fit indicators has the acceptable values or near desirable limit. To investigate convergent validity, three criteria should be considered. The convergent validity of model was confirmed whenever standard factor loads and average variance extracted are higher than 0.5and composite reliability is higher than 0.6 (Fornell \& Larcker, 1981). Table 3 shows that the factor load related to all items is higher than 0.5 , and the composite reliability of all variables is higher than 0.6 , hence the model has convergent validity. Cronbach's alpha coefficient was used to estimate the reliability of questionnaire and evaluate its internal consistency. The value higher than 0.8 was considered completely appropriate.

Table 3

Fit Indicators of Research Measurement Models

\begin{tabular}{lcccccccc}
\hline Indicators & $\mathrm{P}$ & $\mathrm{CMIN} / \mathrm{DF}$ & $\mathrm{RMR}$ & GFI & IFI & TLI & CFI & RMSEA \\
\hline Acceptable Level & $>0.05$ & $<5$ & $<0.05$ & $>0.90$ & $>0.90$ & $>0.90$ & $>0.90$ & $<0.1$ \\
Transformational Leadership Model & 0.00 & 4.33 & 0.03 & 0.93 & 0.90 & 0.86 & 0.90 & 0.07 \\
Transactional Leadership Model & 0.00 & 7.66 & 0.03 & 0.94 & 0.95 & 0.93 & 0.95 & 0.07 \\
Employee Creativity Model & 0.00 & 5.80 & 0.04 & 0.90 & 0.92 & 0.89 & 0.92 & 0.09 \\
Learning Orientation Model & 0.00 & 5.41 & 0.03 & 0.95 & 0.96 & 0.93 & 0.96 & 0.03 \\
\hline
\end{tabular}

The results of the confirmatory factor analysis of transformational leadership did not reflect the convergent validity of this model. Thus, the questions $2,3,8,14,17,18$, and 20 were eliminated and the confirmatory factor analysis was performed again. The confirmatory factor models of transactional leadership and employees' creativity confirm the convergent validity of model. The confirmatory factor analysis of learning orientation and the significance of regression coefficients at 99 percent confidence level does not represent the convergent validity of this model. Thus, question 50 was eliminated and the confirmatory factor analysis was performed again.

Table 4 shows the results related to significance, standard factor loads, convergent validity, and reliability.

Table 4

Results Related to Significance, Standard Factor Loads, Construct Validity, \& Reliability

\begin{tabular}{lcccccc}
\hline Variable & Items & T-Value & Factor Loading & Cronbach's Alpha & CR & AVE \\
\hline & 1 & - & 0.50 & 0.87 & 0.88 & 0.65 \\
& 4 & 6.79 & 0.53 & & \\
Transformational & 5 & 6.62 & 0.50 & & \\
& 6 & 6.77 & 0.58 & & \\
& 7 & 6.98 & 0.63 & & \\
& 9 & 6.97 & 0.52 & & \\
& 10 & 6.52 & 0.55 & & \\
& 11 & 7.12 & 0.72 & & \\
& 12 & 7.07 & 0.72 & & \\
& 13 & 6.53 & 0.50 & & \\
\hline
\end{tabular}




\begin{tabular}{|c|c|c|c|c|c|c|}
\hline & 15 & 5.52 & 0.65 & & & \\
\hline & 16 & 6.57 & 0.52 & & & \\
\hline & 19 & 6.57 & 0.76 & & & \\
\hline & 21 & - & 0.76 & 0.89 & 0.90 & 0.72 \\
\hline & 22 & 17.33 & 0.73 & & & \\
\hline & 23 & 17.43 & 0.74 & & & \\
\hline Transactional & 24 & 18.39 & 0.79 & & & \\
\hline & 25 & 17.52 & 0.75 & & & \\
\hline & 26 & 17.50 & 0.76 & & & \\
\hline & 27 & 16.79 & 0.72 & & & \\
\hline & 28 & - & 0.65 & 0.91 & 0.92 & 0.63 \\
\hline & 29 & 14.29 & 0.63 & & & \\
\hline & 30 & 14.18 & 0.69 & & & \\
\hline & 31 & 12.50 & 0.60 & & & \\
\hline Fmployee Creativity & 32 & 15.82 & 0.79 & & & \\
\hline 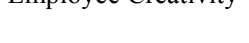 & 33 & 13.00 & 0.63 & & & \\
\hline & 34 & 14.64 & 0.74 & & & \\
\hline & 35 & 13.98 & 0.70 & & & \\
\hline & 36 & 15.09 & 0.78 & & & \\
\hline & 37 & 13.10 & 0.65 & & & \\
\hline & 38 & 15.25 & 0.77 & & & \\
\hline & 39 & 12.23 & 0.59 & & & \\
\hline & 40 & 10.52 & 0.50 & & & \\
\hline & 41 & - & 0.63 & 0.88 & 0.90 & 0.69 \\
\hline & 42 & 12.65 & 0.56 & & & \\
\hline & 43 & 14.75 & 0.81 & & & \\
\hline LO & 44 & 14.09 & 0.80 & & & \\
\hline & 45 & 14.47 & 0.82 & & & \\
\hline & 46 & 12.64 & 0.64 & & & \\
\hline & 47 & 12.37 & 0.63 & & & \\
\hline & 48 & 11.28 & 0.56 & & & \\
\hline & 49 & 10.57 & 0.52 & & & \\
\hline
\end{tabular}

For determining the discriminant validity, the method which offered by Anderson and Gerbing (1988) was used in which the correlation between structures were estimated. Its value was less than 0.85 , so that the discriminant validity was confirmed. Otherwise, it shows how the two structures can measure a similar concept. Since all correlations had values less than 0.85 , the discriminant validity was confirmed. The existence of multiple common linear relationships between the variables with regard to the point that the values of correlations were less than 0.8 was rejected. Table 5 manifests the correlation between variables under study.

Table 5

Correlation between Variables under Study

$\begin{array}{lllll}\mathrm{SD} & 1 & 2 & 3\end{array}$

\begin{tabular}{llll}
\hline Transformational Leadership & 0.49 & 1.00 & \\
Transactional Leadership & 0.70 & 0.48 & 1.00
\end{tabular}


To check the normality of data distribution, one $\mathrm{K}-\mathrm{S}$ test was run. The normal distribution of the data was confirmed for all variables. Having investigated and confirmed the measurement models in the first step, in the second step the structural equations have been used to test the hypotheses. The indicators such as $t-$ value and Sig were used to test the significance of the hypotheses. $T$-value was obtained by dividing the estimated regression weight to the standard error. According to the significance value (0.05), the $t$-value should be more than 1.96 or less than -1.96. The values less than this value were not regarded important. The values less than 0.05 also indicated to the regression coefficients that were significantly different from zero at 0.99 per cent confidence level. In order to assess the moderating role of learning orientation, moderated structural equation modeling (MSEM) has been used. To assess the moderating variable, the independent variable $(X)$ and moderating variable $(Z)$ should be multiplied to each other. In order to prevent linearity error, the AMOS23 software was used the standardized values of these variables to make the interaction. Figure 2 shows the structural equation models of the first and the third hypotheses.

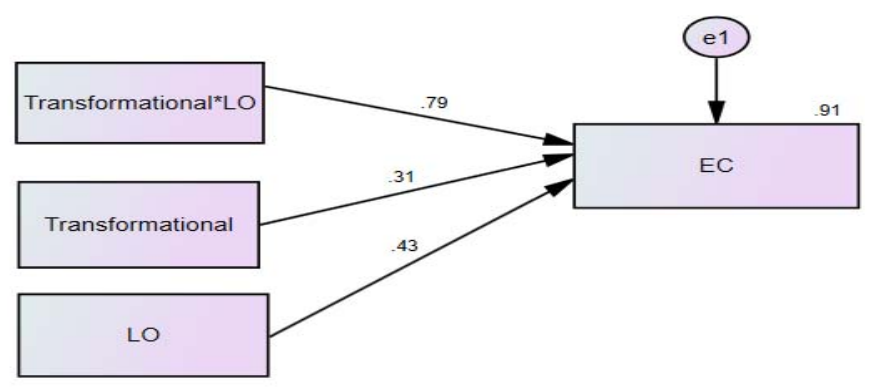

Figure 2. Structural Equations Model of $\mathrm{H}_{01}$ and $\mathrm{H}_{03}$

Table 6 indicates the outcome of fitness indicators with 99 percent confidence level. The indicator value of determinant coefficient $\left(\mathrm{R}^{2}\right)$ which indicated the impact of an exogenous variable on an endogenous variable was 0.91 which was considered as a strong value.

Table 6

Fit Indicators of the Structural Model of the First \& the Second Hypotheses

\begin{tabular}{ccccccccc}
\hline Indicators & P & CMIN/DF & RMR & GFI & IFI & TLI & CFI & RMSEA \\
\hline Hypotheses 1 and 3 & 0.00 & 6.75 & 0.04 & 0.85 & 0.90 & 0.84 & 0.90 & 0.08 \\
Appropriate Level & $>0.05$ & $<5$ & $<0.05$ & $>0.90$ & $>0.90$ & $>0.90$ & $>0.90$ & $<0.1$ \\
\hline
\end{tabular}

The estimated impact coefficient in Table 7 indicates the effectiveness or non-effectiveness of every component. Regarding the first hypothesis, the standardized regression coefficient between two variables of transformational leadership and employees' creativity was estimated (0.31). Since this coefficient was between 0.3 and 0.6 , the transformational leadership had 
positive impact on the employees' creativity. Regarding the third hypothesis, the standardized regression coefficient between (transformational leadership * learning orientation) and employees' creativity was equal to 0.79 , indicating that learning orientation conditions (as much as 0.79 percent) strengthened the impact of transformational leadership on the employees' creativity.

Table 7

Regression Coefficient of the First and the Third Hypotheses

\begin{tabular}{|c|c|c|c|c|c|}
\hline Hypothesis 1 and Hypothesis 3 & $\begin{array}{c}\text { Impact } \\
\text { Coefficient }\end{array}$ & S.D Error & T-Value & Sig. & Results \\
\hline (Transformational Leadership* Learning Orientation) and Creativity & 0.79 & - & - & 0.00 & Confirmed \\
\hline Transformational Leadership and Employee Creativity & 0.31 & 0.14 & 2.20 & 0.00 & Confirmed \\
\hline Learning Orientation and Employee Creativity & 0.43 & 0.11 & 9.12 & 0.00 & Confirmed \\
\hline
\end{tabular}

In Table 8, about the fourth hypotheses, the outcomes of fit indicators were offered at 99 percent confidence level. The indicator value of $\mathrm{R}^{2}$ for this model was 0.42 which was considered a medium value.

Table 8

Fit Indicators of the Structural Model of the Second \& the Fourth Hypotheses

\begin{tabular}{ccccccccc}
\hline Indicators & $\mathrm{P}$ & $\mathrm{CMIN} / \mathrm{DF}$ & $\mathrm{RMR}$ & IFI & TLI & CFI & RMSEA \\
\hline Hypotheses 2 and 4 & 0.00 & 4.73 & 0.04 & 0.92 & 0.89 & 0.92 & 0.08 \\
Appropriate Level & $>0.05$ & $<5$ & $<0.05$ & $>0.90$ & $>0.90$ & $>0.90$ & $<0.1$ \\
\hline
\end{tabular}

In Table 9, the estimated impact coefficient indicates the effectiveness or non-effectiveness of every component.

Table 9

Regression Coefficient of the Second \& the Fourth Hypotheses

\begin{tabular}{lccccc}
\hline Hypothesis 2 and Hypothesis 4 & $\begin{array}{c}\text { Impact } \\
\text { Coefficient }\end{array}$ & S.D Error & T-Value & Sig. & Result \\
\hline (Transactional Leadership* Learning Orientation ) and Creativity & 0.19 & 0.67 & 1.55 & 0.11 & Rejected \\
Transactional Leadership and Employee Creativity & 0.34 & 0.13 & 2.18 & 0.00 & Confirmed \\
Learning Orientation and Employee Creativity & 0.39 & 0.14 & 1.22 & 0.53 & Rejected \\
\hline
\end{tabular}

To answer the second hypothesis, the standardized regression coefficient between two variables of transactional leadership and employees' creativity was estimated (0.34).Due to the range of coefficient values which was between 0.3 and 0.6 transactional leadership had a positive impact on the employees' creativity. Regarding the fourth hypothesis, the standardized regression coefficient between (transactional leadership * learning orientation) and employees' creativity was equal to 0.19 and the $t$-value was equal to 1.55 . Thus, it can be concluded that the hypothesis was not confirmed at 99 percent confidence level. In other word, there was not any significant relationship between transactional leadership and the employees' creativity with regard to the moderating role of learning orientation. According to Table 10, the outcome of fit indicators did not confirm the model at 99 per cent confidence. 
Table 10

Fit Indicators of the Structural Model of the Fourth Hypothesis

\begin{tabular}{lccccccc}
\hline Indicators & $\mathrm{P}$ & $\mathrm{CMIN} / \mathrm{DF}$ & $\mathrm{RMR}$ & IFI & TLI & CFI & RMSEA \\
\hline S1 and S2 & 0.00 & 3.25 & 0.04 & 0.83 & 0.87 & 0.90 & 0.06 \\
Appropriate Level & $>0.05$ & $<5$ & $<0.05$ & $>0.90$ & $>0.90$ & $>0.90$ & $<0.1$ \\
\hline
\end{tabular}

To investigate the moderating role of gender, 311 females and 237 males were selected from the sample $(\mathrm{n}=548)$. Since the absolute value of $t$-value ratio, which reflected the differences between S1 (female) and S2 (male) at 99 percent confidence level, was equal to 0.00 , and less than 1.96; hence, the existence of significant differences between male and female was rejected.

According to the Table 11, two models $\left(\mathrm{S}_{3}\right.$ and $\left.\mathrm{S}_{4}\right)$ which performs in one fit presents in two separate figures.

Table 11

Fit Indicators of the Structural Model of H6

\begin{tabular}{ccccccccc}
\hline Indicators & P & CMIN/DF & RMR & GFI & IFI & TLI & CFI & RMSEA \\
\hline S3 and S4 & 0.00 & 3.40 & 0.04 & 0.83 & 0.91 & 0.86 & 0.91 & 0.06 \\
Appropriate Level & $>0.05$ & $<5$ & $<0.05$ & $>0.90$ & $>0.90$ & $>0.90$ & $>0.90$ & $<0.1$ \\
\hline
\end{tabular}

The outcome of fit indicators did not confirm the model at 99 percent confidence. Therefore, the model needed modifications. After doing modifications, the fit indicators confirmed the model at 99 percent confidence level. To investigate the moderating role of gender with regard to the performed calculations from the sample $(n=548)$ data, 311 females and 237 males were chosen. Regarding the difference between the absolute $\mathrm{t}-$ values of models $\left(\mathrm{S}_{3}\right.$ and $\left.\mathrm{S}_{4}\right)$ at 99 percent confidence level which was equal to 2.45and more than 1.96; the existence of significant difference between two models including $\mathrm{S}_{3}$ and $\mathrm{S}_{4}$ was confirmed. In other word, the moderating impact of females between two variables including transactional leaders and employees' creativity was equal to 0.82 while the moderating impact of males between two variables of transactional leaders and employees' creativity was 0.86 . The moderating impact of males in comparison to females was higher. Thus, the male transactional leaders in comparison to female transactional leaders had more impact on the employees' creativity of education and training.

\section{Discussion and Conclusion}

The lack of experimental evidences about the impact of transformational and transactional leadership styles on the education of employees' creativity considering the moderating roles of learning orientation and leader's gender. This research investigates different domains of transformational leadership, transactional leadership, employees 'creativity, learning orientation, and leader's gender. Through running statistical software, the mutual impacts of variables on each other were investigated. Then, the accuracy of model and its fit based on the collected experimental data was assessed to cover the gap between theoretical topics and what 
occur in practice. By using exploratory factor analysis method and confirmatory factor analysis, the research tried to fulfill the exploratory and confirmatory objectives. The results revealed that within transformational leadership measurement model and employees' creativity measurement model, there were some items which did not have appropriate factor load. Furthermore, their primary fit indicators were not desirable. Therefore, these items were put aside from the research process and factor analysis was performed on these variables again because good performance cannot be expected of the weak items. Considering the fact that the leaders can impact on their subordinates' thoughts, feelings, wishes, motivation, and behaviors, so their leadership styles can act as facilitator or inhibitor factor directly or indirectly on their subordinates' creativity. Regarding the relationship between transactional leadership and employees' creativity considering the moderating role of learning orientation, the findings of this study showed that there was no significant relationship between transactional leadership and employees' creativity. This hypothesis was in line with the findings of Amitay et al. (2005) who stated that there was a negative relationship between transactional leadership and learning orientation. The results showed that transactional leadership style was not appropriate factor for creating employees' creativity in the education and training organization. The interesting point was the impact of transformational leadership style on the employees' creativity; because it was destroyed after the impact of moderator such as orientation learning. The short-term results or disregarding long-term programs of transactional leadership style probably were considered as the reasons that reduce the employees' and teachers' interest rates in education and training organizations. This issue could refer to some weaknesses of this leadership style in the dynamic educational system. Furthermore, transformational leadership style enjoys high levels of favorability in the education and training organizations. Patnaik et al. (2013) emphasized on the importance of transformational leadership in the educational organizations and considered this leadership style as essential one for creating long term commitment in organizations. Actually, the results confirmed that the significant impact of transformational leadership style on learning orientation (Coad \& Berry, 1998; Chang \& Lee, 2007; Jansen et al., 2009; Kurland et al., 2010; Nafei et al., 2012; Theodore, 2013).The results also showed that both male and female managers who had transformational leadership styles influenced on their employees' creativity. Furthermore, the results showed that female leaders were more transformational which was in line with some previous studies (Bass, 1999; Carless, 1998; Northouse, 2007). The findings also revealed that there was a relationship between transactional leadership and employees' creativity in two groups of managers in the education and training organizations and male managers were more successful in transactional leadership behaviors.

As proposed in the management of human resources, the duties of the manager towards the employees are of especial importance, because of a role that each member plays in the organization. The manager is considered as a stage director who has the ability and skill to coordinate the activities of all members for achieving the determined objectives. So, the success of managerial performances depends on the cooperation and sympathy of all members of the organization and hence the manager's behavior. It is achieved through paying attention to their employees 'security, social and personality needs, and defending their rights. The manager of school shall recruit the appropriate and concordant administrative and teaching 
staff for the school. In this case the selection of teachers commensurate with the socio-cultural context of the region and also the selection of deputies having managerial features and skills is essential. Based on the expressed expectations the performance of the employees should be evaluated and any rewards and encouragements should be based on evaluation results. Evaluating the work of the educational members should be in a way that the truthful and active teachers could be distinguished and recognized from the uninterested ones. Sometimes, it is necessary to think about the topics beyond performing the everyday duty. Although teachers usually participate in the meetings along with headmasters, but the previous preparation and interest in the issues of the council and active and responsible participation in meetings with creative ideas have a value more than merely uninterested participation.

One of the major tasks of the managers towards the employees is encouraging them to participate in decision-making processes, in particular, those decisions that are related to their work future. Valuing the council, creating a platform of creativity, and innovation in school are of great importance in conducting a survey, delegating the authority of decision to the people, and considering people's view as the basis of the decisions. The result of attaching importance to creativity and innovation in education is because of existence of a dynamic and knowledgebased organization.

One of the main limitations of this study is its ungeneralizablity. It is recommended that in the future research, there is an urgent need to have a longitudinal plan instead of having a cross-sectional approach, since the longitudinal research can fully specify the interactive and dynamic nature of many variables and explain their causal relationships. Despite offering a rich literature in the area of the leadership and employees' creativity, this research could be still studied by means of the new models and adding other influential variables; for instance, in addition to the adjusted role of the schools headmasters' education or their work experience. Being determined the extent of the impact of these variables regarding the type of leadership styles of headmasters and the extent of impact on employees' creativity, we can study the research based on other aspects. The findings of this study reflected the organizational results of variables in governmental organizations, so we should be cautious in generalizing and using the findings of this findings research in private organizations. Future researchers are suggested to use the leadership models presented in this research by adding the appropriate variables in other sectors such as industry.

\section{References}

Amabile, T. M. (1996), Creativity in context, Boulder, CO: Westview.

Amabile, T. (1997). Entrepreneurial creativity through motivational synergy. Journal of Creative Behavior, 31(1), 18-26.

Amabile, T. M., Mueller, J. S., Simpson,W. B., Hadley, C. N., Kramer, S. J., \& Fleming, L. (2002). Time pressures and Creativity in organizations: A longitudinal field study. Harvard Business School Working, No. 02-073.

Amabile, T. M., Schatzel, E. A., Moneta, G. B., \& Kramer, S.J. (2004). Leader behaviors and the work environment for creativity: Perceived leader support. The Leadership Quarterly, 15(1), 5-32.

Amitay, M., Popper, M., \& Lipshitz, R. (2005). Leadership styles and organizational learning in community clinics. The Learning Organization, 12(1), 57-70.

Anderson, J. C., \& Gerbing, D. W. (1988). Structural equation modeling in practice: A review and recommended two-step approach. Psychological Bulletin, 103(3), 411-423. 
Andrews, F. M., \& Farris, G. F. (1967). Supervisory practices and innovation in scientific teams. Personnel Psychology, 20(4), 497-515.

Argyris, C., \& Schon, DA. (1978). Organizational Learning: A Theory of Action Perspective, Addison- Wesley, Reading, MA.

Argyris, C. and Schon, A.D. (1996). Organizational Learning II: Theory, Method, and Practice, Addison-Wesley, Boston, MA.

Bai, Y., Lin, L., \& Li, p.p. (2016). How to enable employee creativity in a team context: A cross-level mediating process of transformational leadership. Journal of Business Research, 69(9), 3240-3250.

Bass, B. M. (1985). Leadership and Performance Beyond Expectations, The Free Press, New York, NY.

Bass, B. M. (1998). Transformational Leadership: Industrial, Military, and Educational Impact, Erlbawm, NJ.

Bass, B. M. (1999). Two decades of research and development in transformational leadership. European Journal of Work and Organizational Psychology, 8(1), 9-32.

Bass, B. M., \& Avolio, B. J. (1994). Improving Organizational Effectiveness through Transformational Leadership, Sage Publication Inc., Thousand Oaks, CA.

Bass, B. M., \& Avolio, B. J. (1995). MLQ Multifactor Leadership Questionnaire (Form 5x-short). Redwood City, CA: Mind Garden.

Bass, B. M., \& Avolio, B. J. (2004). Multifactor Leadership Questionnaire: Manual and Sample Set, 3rd ed., Mind Garden, Redwood City, CA.

Berkovich, I. (2016). School leaders and transformational leadership theory: time to part ways? Journal of Educational Administration, 54(5), 609-622.

Billett, S., Fenwick, T., \& Somerville, M. (2006). Work, Subjectivity, and Learning: Understanding Learning through Working Life, Dordrecht: Springer.

Brandt, T., \& Laiho, M. (2013). Gender and personality in transformational leadership context. Leadership \& Organization Development Journal, 34(1), 44-66.

Bogler, R. (2001). The influence of leadership style on teacher job satisfaction. Educational Administration Quarterly, 37(5), $662-683$.

Brenner, O. C., Tomkiewicz, J., \& Schein, V. E. (1989). The relationship between sex role stereotypes and requisite management characteristics revisited. Academy of Management Journal, 32(3), 662-9.

Brown, F. W., \& Reilly, M. D. (2008). Emotional intelligence, transformational leadership and gender: correlation and interaction possibilities. The Journal of International Management Studies, 3(2), 1-9.

Burns, J.M. (1978). Leadership, Harper \& Row, New York, NY.

Bush, T. (2014). Instructional and transformational leadership: alternative and complementary models? Educational Management Administration and Leadership, 42(4), 443-444.

Calantone, R. J., Cavusgil, S. T., \& Zhao, Y. (2002). Learning orientation, firm innovation capability, and firm performance. Industrial Marketing Management, 31(6), 515-524.

Carless, S.A. (1998). Gender differences in transformational leadership: an examination of superior, leader, and subordinate perspectives. Sex Roles, 39(11/12), 887-902.

Carneiro, A. (2000). How does knowledge management influence innovation and competitiveness?. Journal of Knowledge Management, 4(2), 87-98.

Carson, P. P., \& Carson, K. D. (1993). Managing creativity enhancement through goal-setting and feedback. Journal of Creative Behavior, 27(1), 36-45.

Chang, S., \& Lee, M. (2007). A study on relationship among leadership, organizational culture, the operation of learning organization and employees' job satisfaction. The Learning Organization, 14(2), 155-185.

Chu, L.C., \& Lai, C.C. (2011). A research on the influence of leadership style and job characteristics on job performance among accountants of county and city government in Taiwan. Public Personnel Management, 40(2), 101-118.

Coad, A., \& Berry, A. (1998). Transformational leadership and learning orientation. Leadership and Organization Development Journal, 19(3), 164-172.

Cohen, W., \& Levinthal, D. (1990). Absorptive capacity: A new perspective on learning and innovation. Administrative Science Quarterly, 35(1), 128-152.

Darroch, J., \& McNaughton, R. (2002). Examining the link between knowledge management practices and types of innovation”. Journal of Intellectual Capital, 3(3), 210-22. 
Deci, E. L., \& Ryan, R.M. (1987). The support of autonomy and the control of behavior. Journal of Personality and Social Psychology, 53(6), 1024-1037.

Dvir, T., Eden, D., Avolio, B.J., \& Shamir, B. (2002). Impact of transformational leadership on follower development and performance: A field experiment. Academy of Management Journal, 45(4), 735-744.

Dyer, J. H., \& Singh, H. (1998). The relational view: Competitive strategy and sources of interorganizational competitive advantage". Academy of Management Review, 23(4), 660-679.

Eagly, A. H., Karau, S. J., \& Makhijani, M. G. (1995). Gender and the effectiveness of leaders manage: a meta-analysis”. Psychological Bulletin, 117(1), 125-45.

Eagly, A. H., Makhijani, M. G., \& Klonsky, B. G. (1992). Gender and the evaluation of leaders: a meta-analysis. Psychological Bulletin, 111(1), 3-22.

Edmondson, A. C. (1999). Psychological safety and learning behavior in work teams. Administrative Science Quarterly, 44(2), $350-383$.

Eyal, O., \& Roth, G. (2011). Principals' leadership and teachers' motivation: self-determination theory analysis. Journal of Educational Administration, 49(3), 256-275.

Fornell, C., \& Larcker, F. (1981). Evaluating structural equation models with unobservable variables and measurement error. Journal of Marketing Research, 18(1), 39-50.

Grant, R. M. (1996). Toward a knowledge-based theory of the firm. Strategic Management Journal, 17(s2), 109-122 (special issue).

Harris, R. B., \& Harris, K. J. (2007). A Test of competing models of the relationships among perceptions of organizational politics, perceived organizational support, and individual outcomes. The Journal of Social Psychology, 147(6), 631-655.

Hodkinson, H., \& Hodkinson, P. (2005). Improving Schoolteachers' Workplace Learning. Research Papers in Education, 20(2), 109-131.

Hallinger, P. (1992). The evolving role of American principals: from managerial to instructional to transformational leaders. Journal of Educational Administration, 30(3), 35-48.

Hallinger, P. (2003). Leading educational change: reflections on the practice of instructional and transformational leadership. Cambridge Journal of Education, 33(3), 329-352.

Howell, J. M., \& Avolio, B. J. (1993). Transformational leadership, transactional leadership, locus of control, and support for innovation: Key predictors of consolidated-business-unit-performance. Journal of Applied Psychology, 78(6), 891-902.

Hoyt, C. L., Simon, S., \& Reid, L. (2009). Choosing the best (wo) man for the job: the effects of mortality salience, sex, and gender stereotypes on leader evaluations. The Leadership Quarterly, 20(2), 233-46.

Hsiao, H. C., \& Chang, J. C. (2011). The role of organizational learning in transformational leadership and organizational innovation. Asia Pacific Education Review, 12(4), 621-631.

Huber, G. P. (1991). Organizational learning: The contributing processes and the literatures. Organization Science, 2(1), 88115.

Hurley, R. F., \& Hult, T. M. (1998). Innovation, market orientation and organizational learning: an integration and empirical examination. Journal of Marketing, 62(3), 42-54.

Jansen, J. J. P., Vera, D., \& Crossan, M. (2009). Strategic leadership for exploration and exploitation: the moderating role of environmental dynamism. The Leadership Quarterly, 20(1), 5-18.

Jaskyte, K., \& Kisieliene, A. (2006). Determinants of Employee Creativity: A Survey of Lithuanian Nonprofit Organizations. International Journal of Voluntary and Nonprofit Organizations, 17(128), 133-141.

Joo, B. K. B., McLean, G. N., \& Yang, B. (2013). Creativity and human resource development an integrative literature review and a conceptual framework for future research. Human Resource Development Review, 12(4), 390-421.

Judge, T. A., \& Piccolo, R. F. (2004). Transformational and transactional leadership: a meta-analytic test of their relative validity. Journal of Applied Psychology, 89(1), 755-768.

Jyoti, J., \& Dev, M. (2015). The impact of transformational leadership on employee creativity: the role of learning orientation. Journal of Asia Business Studies, 9(1), 78-98.

Kaya, N., \& Patton, J. (2011). The effects of knowledge-based resources, market orientation and learning orientation on innovation performance: an empirical study of Turkish firms. Journal of International Development, 23(2), $204-219$.

Kent, T. W., Blair, C. A., Rudd, H. F., \& Schuele, U. (2010). Gender differences and transformational leadership behavior: do both German men and women lead in the same way? International Journal of Leadership Studies, 6(1), 52-66. 
Khalifa, B., \& Ayoubi, R. M. (2015). Leadership styles at Syrian higher education. International Journal of Educational Management, 29(4), $477-491$.

Kurland, H., Peretz, H., \& Hertz-Lazarowitz, R. (2010). Leadership style and organizational learning: the mediate effect of school vision”. Journal of Educational Administration, 48(1), 7-30.

Leithwood, K. (1994). Leadership for school restructuring. Educational Administration Quarterly, 30(4), 498-518.

Leithwood, K., \& Sun, J. (2012). The nature and effects of transformational school leadership: a meta-analytic review of unpublished research. Educational Administration Quarterly, 48(3), 387-423.

Manning, T.T. (2002). Gender, managerial level, transformational leadership and work satisfaction. Women in Management Review, 17(5), 207-16.

Masa'deh, R., Obeidat, B.Y., \& Tarhini, A. (2016).A Jordanian empirical study of the associations among transformational leadership, transactional leadership, knowledge sharing, job performance, and firm performance: A structural equation modelling approach. Journal of Management Development, 35(5), 681-705.

Menon, M. E. (2014).The relationship between transformational leadership, perceived leader effectiveness and teachers' job satisfaction. Journal of Educational Administration, 52(4), 509-528.

Mittal, S., \& Dhar, R.L. (2015). Transformational leadership and employee creativity. Management Decision, 53(5), 894-910.

Moorman, C., \& Miner, A. (1998). Organizational improvisation and organizational memory. The Academy of Management Review, 23(4), 698-724.

Mushtaq, R., \& Bokhari, R.H. (2011). Knowledge sharing: organizational culture and transformational leadership. Journal of Knowledge Management Practice, 12(2), 1-9.

Muthusamy, S. K., \& White, M. A. (2005). Learning and knowledge transfer in strategic alliances: A social exchange view. Organization Studies, 26(3), 415-441.

Nafei, W. A., Khanfar, N. M., \& Kaifi, B. A. (2012). Leadership styles and organizational learning an empirical study on Saudi banks in Al-Taif governorate kingdom of Saudi Arabia. Journal of Management and Strategy, 3(1), 2-17.

Nasution, H. N., Mavondo, F. T., Matanda, M. J., \& Ndubisi, N. O. (2011). Entrepreneurship: Its relationship with market orientation and learning orientation and as antecedents to innovation and customer value. Industrial Marketing Management, 40(3), 336-345.

Nir, A. E., \& Hameiri, L. (2014). School principals' leadership style and school outcomes: the mediating effect of powerbase utilization. Journal of Educational Administration, 52(2), 210-227.

Northouse, P. G. (2007). Leadership Theory and Practice, 4th ed., Sage Publications, Thousand Oaks, CA.

Odumeru, J. A., \& Ifeanyi, G. O. (2013).Transformational vs transactional leadership theories: evidence in literature. International Review of Management and Business Research, 2(2), 355-361.

Oldham, G. R., \& Cummings, A. (1996). Employee creativity: Personal and contextual factors at work. Academy of Management Journal, 39(3), 607-634.

Opfer, V. D., Pedder, D. G., \& Lavicza, Z. (2011). The Role of Teachers' Orientation to Learning in Professional Development and Change: A National Study of Teachers in England. Teaching and Teacher Education, 27(2), 443-453.

Oyster, C.K. (1992).Perceptions of power. Psychology of Women Quarterly, 16(4), 527-33.

Patnaik, B., Beriha, G. S., Mahapatra, S. S., \& Singh, N. (2013). Organizational learning in educational settings (technical): an Indian perspective. The Learning Organization, 20(2), 153-172.

Rafferty, A. E., \& Griffin, M. A. (2004). Dimensions of transformational leadership: conceptual and empirical extensions. The Leadership Quarterly, 15(3), 329-54.

Retallick, J. (1999).Teachers' Workplace Learning: Towards Legitimation and Accreditation. Teachers and Teaching, 5(1), $33-50$.

Sadler, P. (2003). Leadership, $2^{\text {nd }}$ ed., Kogan Page, London.

Schein, E. H. (1993). How can organizations learn faster? The challenge of entering the greenroom. Sloan Management Review, 34(2), 85-92.

Shalley, Ch. E., \& Gilson, L. L. (2004). What leaders need ti know: A review of social and contextual factors that can foster or hinder creativity. The Leadership Quarterly, 15(1), 33-53.

Shalley, C. E., Zhou, J., \& Oldham, G. R. (2004). Effects of personal and contextual characteristics on creativity. Journal of Management, 30(6), 933-958.

Shin, S. J., \& Zhou, J. (2003). Transformational leadership, conservation, and creativity: Evidence from Korea. Academy of Management Journal, 46(6), 703-714. 
Si, S., \& Wei, F. (2012).Transformational and transactional leaderships, empowerment climate, and innovation performance:A multilevel analysis in the Chinese context. European Journal of Work and Organizational Psychology, 21(2), $299-320$.

Spence, J.T., \& Helmreich, R. L. (1978). Masculinity and Feminity: Their Psychological Dimensions, Correlates, and Antecedents, University of Texas Press, Austin, TX.

Tabachnick, B., \& Fidell, L. S. (1996). Using multivariate statistics, NEWYORK: Happer Collins College.

Theodore, J. (2013). Absence of transformational leadership in Greek enterprises results in the inability of forming learning organizations. International Business \& Economics Research Journal, 12(6), 701-706.

Tierney, P. (2008). Leadership and employee creativity. Handbook of organizational creativity, 95-123.

Van Knippenberg, D., \& Sitkin, S.B. (2013).A critical assessment of charismatic transformational leadership research: back to the drawing board? The Academy of Management Annals, 7(1), 1-60.

Vera, D., \& Crossan, M. (2004). Strategic leadership and organizational learning. Academy of Management Review, 29(2), $222-240$.

Wang, A.C., \& Cheng, B.S. (2010).When does benevolent leadership lead to creativity? The moderating role of creative role identity and job autonomy. Journal of Organisational Behavior, 31(1), 106-121.

Wang, A. C., Chiang, J. T. J., Tsai, C.Y., Lin, T.T., \& Cheng, B. S. (2013). Gender makes the difference: The moderating role of leader gender on the relationship between leadership styles and subordinate performance. Organizational Behavior and Human Decision Processes, 122(2), 101-113.

Wang, L. H., Gurr, D., \& Drysdale, L. (2016). Successful school leadership: case studies of four Singapore primary schools. Journal of Educational Administration, 54(3), 270-287.

Wang, P., \& Rode, J. C. (2010).Transformational leadership and follower creativity: The moderating effects of identification with leader and organizational climate. Human Relations, 63(8), 1105-1128.

Wang, X., \& Howell, J. M. (2010). Exploring the dual-level effects of transformational leadership on followers. Journal of Applied Psychology, 56(3), 1-11.

West, M. A. (1989). Innovation amongst health care professionals. Social Behavior, 4,173-184.

Williams, J. E., \& Best, D. L. (1982). Measuring Sex Stereotypes: A Thirty Nation Study, Sage, Beverly Hills, CA.

Yahaya, R., \& Ebrahim, F. (2016). Leadership styles and organizational commitment: literature review. Journal of Management Development, 35(2), 190-216.

Yang, Y. (2014). Principals' transformational leadership in school improvement. International Journal of Educational Management, 28(3), 279-288.

Yulk, G.A. (2010). Leadership in Organizations, 7th ed., Prentice Hall, Upper Saddle River, NJ.

Zander, U. and Kogut, B. (1995). Knowledge and the speed of the transfer and imitation of organizational capabilities: An empirical test. Organization Science, 6(1), 76-92.

Zhou, J. (2003). When the presence of creative coworkers is related to creativity: role of supervisor close monitoring, developmental feedback, and creative personality. Journal of Applied Psychology, 88(3), 413-422.

Zhou, J., \& Shalley, C. E. (2008). Handbook of organizational creativity, Lawrence Erlbaum Associates, New York. 